The original publication is available at http://www.tandf.co.uk/journals/

\title{
Distribution and Characterization of Tar Ball Pollution on Beaches in Brittany (France) and Indonesia
}

\author{
G. Bodennec ${ }^{a}$, L. Loubersac ${ }^{a} \&$ J. Bilal ${ }^{b}$ \\ a IFREMER, Centre de Brest, B.P. 337, 29273, Brest, France \\ b Oil and Gas Technology Development Center LEMIGAS, B.P. 89 JKT, Jakarta, Indonesia
}

\begin{abstract}
:
Stranded tar along the Brittany coast and four test sites in Indonesia (Jakarta Bay, Malacca and Makassar Straits, Central South Java) were surveyed in 1982 in order to quantify and identify the possible origin of oil pollutants. The estimation of tar pollution was determined by a statistical methodology based on a stratified random sampling. Western Brittany and Jakarta Bay must be regarded among the areas most vulnerable to chronic oil pollution with respectively gross weight values of $76.9 \pm 115.6 \mathrm{~g} / \mathrm{m}$ and $812.7 \pm 219 \mathrm{~g} / \mathrm{m}$, comparable to those of other coasts along major tanker routes such as Kuwait or Bermuda. The levels on the other sampled sites were relatively low in spite of such dense maritime traffic as in Malacca straits $(15.4 \pm 5.4 \mathrm{~g} / \mathrm{m})$ or near the mouth of La Loire $(12.2 \pm 15.9 \mathrm{~g} / \mathrm{m}$ and less than $0.5 \mathrm{~g} / \mathrm{m}$ in the Bay of Saint-Brieuc).
\end{abstract}

Hydrocarbons in tar samples were examined by liquid and gas chromatography for a classification in crude oil residues, sludge residues and fuel oil. A multimethod approach combining GC, IR, SFUV and sulfur content was used for a characterization of oil extracts and their tentative matching with the physico-chemical parameters of some reference oils.

Keywords: Stranded tar pollution ; quantitative assessment ; possible sources and origins ; coastal pollution in Brittany and Indonesia 


\section{INTRODUCTION}

The presence of petroleum residues on beaches is becoming a widespread phenomenon in every coastal country. The oil entering the marine environment comes from various sources: accidental or intentional oil spillages resulting from offshore activities and tanker traffic, natural submarine oil seepages, domestic and industrial petroleum waste discharges from coastal rivers or factories and atmospheric fall-out. Among these sources, the oil spillage from tank washing and deballasting operations at sea seems to be the main contributory factor in the extensive damage to marine life and seaside resorts through the accumulation of tar balls on account of their heavy and punctual inputs. The growing amount of petroleum products carried by tankers or exploited by offshore platforms may increase the level of coastal pollution. The National Academy of Science ${ }^{1}$ has shown that there exists a very close correlation between the density of tar residues washed ashore and the maritime lanes used by tankers. The most sensitive zonesare located in areas of oil production and near tanker routes especially in enclosed seas: Persian Gulf, Red Sea, Mediterranean Sea, Gulf of Mexico, or near some important straits and capes. Most particularly the shorelines of Brittany (Francé) and Indonesia are characterized by an intense tanker traffic in the direct vicinity of the coastline. An average of 180 freighters including 15 tankers are indexed every day at the English Channel western entrance. A similar tanker traffic could be expected near Indonesian coasts since more than $90 \%$ of the oil supply for the Pacific countries, particularly Japan and the United States is shipped from the Middle East through the Malacca and Makassar Straits (Indonesia). So the shorelines of Indonesia and Brittany could be among the areas most exposed to oil pollution. It could be interesting to compare the level and the source of tar contamination in these two areas characterized by differences in the geographical location, hydrographical and topographical features. 
This paper deals with the two following objectives firstly to quantify the tar pollution level on different Breton and Indonesian test sites, secondly to identify the possible origin of coastal oil pollution through the characterization of tar residues.

\section{I - DESCRIPTION OF THE STUDIED SITES}

\section{I.1. - The coast of Brittany}

The shoreline is characterized by a succession of protruding headlands, large bays and sheltered salt marshes. Tides, strongly prograding on the northern coast from west to east, have a range of 6 to $9 \mathrm{~m}$ disengaging large tidal flats. So under the actions of both tidal currents and N.W. winds tar residues and other litters discharged at sea are generally accumulating in the upper part of the foreshore open to the west. Low pressure areas formed in the North Atlantic are responsible for strong westerly winds and high seas. So on account of a dangerously jagged coastline, severe weather conditions and high level of marine transportation, the northern coast of Brittany has recently been heavily polluted with several oil spills: BOLHEN 1976, OLYMPIC BRAVERY 1976, AMOCO CADIZ 1978, GINO 1979, TANIO 1980. Since all these tanker accidents occurred in winter, our tar ball survey

(fig. 1) was carried out from October 1982 to February 1983. More than 80 field stations stretching from the mouth of La Loire to Saint-Malo were sampled. (fig. 1)

\section{I.2. - The Indonesian test sites.}

Indonesia is situated between $95^{\circ}$ and $141^{\circ}$ longitude and between $6^{\circ}$ North and $11^{\circ}$ South latitude. It is composed of 13.677 islands with a total coastline length of approximately $81.000 \mathrm{~km}$. Being located on the equator, Indonesia has a tropical climate with warm and stable temperatures handing from $20^{\circ}$ to $32^{\circ} \mathrm{C}$. The climate is completely controlled by monsoon with westerly winds from April to October and north-easterly winds during the remainder of the year. Winds and 
surface currents play the major role in the direction of oil slicks and floating tar drift 2 . The tide is mainly semi-diurnal with mean range of about $2 \mathrm{~m}$. The islands, which display a considerable coastal diversity, are mostly mangrove swamps mainly composed of sonneriata and rhizophora with sometimes at low tide large expanses of mudflats. Sandy beaches and coral reefs are common and well distributed throughout the archipelago. Based on considerations about prevailing currents, oil activities location and shipping routes, four test sites namely Kepulauan Seribu, Kepulauan Riau, the southern-west coast of Sulawesi (Langga beach) and the south coast of Java near Jogjakarta were observed and surveyed in August 1982 (east monsoon) and

fig. 2. in May 1984 (west monsoon). The location of the test sites is indicated in fig. 2 . Kepulauan Seribu is an archipelago located in the Java sea at about $40 \mathrm{~km}$ to the northwest of Jakarta. Two islands: Pulau Pari and Pulau Tikus were selected in this archipelago during our 1982 and 1984 surveys. Kepulauan Riau is an archipelago situated south of Singapore island in the Malacca Straits. Numerous oil terminals and refineries with some productive offshore fields located on both sides of the Straits could be, with their intense traffic, regarded as oil and tar pollution sources. Five islands were sampled in the main strait. Langga beach located about $180 \mathrm{~km}$ north of Ujung Pandang was the only test site surveyed on the south-western coast of Sulawesi. This sandy beach is an area representative of chronic tar pollution from oil transportation in the Makassar straits. The test sites on the south coast of Java are composed of two beaches Krakal and Kukup (near Jogjakarta) well exposed to the open ocean swell.

\section{II - SAMPLING AND ANALYTICAL METHODS}

\section{II.1 - Quantitative assessm ent of tar pollution}

The aim of the developed methodology is to obtain an estimation as precise as possible of the quantity of stranded tar over a determined test site, taking into account that the tar loading are not homogeneous. The stratified random 
sampling adopted in this study has the advantage of giving a good precision of the estimated mean and of notably minimizing the variance of this mean. Briefly the sampling methodology could be divided into two steps.

* The first step is made of a rapid reconnaissance of the test area in order to divide it into strata representative of a type of accumulation (i.e. very high, medium, low...) each of which is internally homogeneous.

* The second consists in selecting, in each stratum, a random sampling composed of $\mathbf{n}$ beach profiles in which all surface tars are collected in a $1 \mathrm{~m}$ wide strip of beach extending from the waterline at the time of sampling to the extreme upper line of the investigated zone. Tar concentrations are expressed in grams per linear meter of beach $(\mathrm{g} / \mathrm{m})$. This unit has the advantage being independent of beach width and tide level. Usually tar is concentrated in distinct bands parallel to the water line, which facilitates cleanup but makes the usefulness of expressing its concentration in units of $\mathrm{g} / \mathrm{m}^{2}$ (as it is in the IGOSS methodology ${ }^{3}$ ) questionable.

For data processing the following formulas were used in a computerized program in order to estimate tar concentration and confidence limits of the sampled area. $N=N_{1}+N_{2}+\ldots N_{L}=$ total number of units (L strata). The suffix $h$ denotes the stratum $h$ with total length $\mathrm{N}_{h}$.

$\mathrm{nh}=$ total number of sampling units taken in stratum $h$.

$Y_{h i}=$ value of the $i$ th unit in the stratum $h$

$w_{h}=\frac{{ }_{h}}{N}=$ stratum weight.

$\mathrm{E}_{\mathrm{h}}=\frac{\mathrm{n}_{\mathrm{h}}}{\mathrm{N}_{\mathrm{h}}}=$ sampling fraction in the stratum. 
- Estimation of the mean per unit over the whole population

$$
\bar{y}_{s t}=\sum_{h=1}^{L} \frac{N_{h} \bar{y}_{h}}{N} \quad \text { Sample mean : } \bar{y}_{h}=\sum_{i=1}^{n_{h i}} \cdot \frac{y_{h i}}{n_{h}}
$$

- Estimation of the standard deviation $s_{h}$ in stratum $h$.

$s_{h} \sqrt{\frac{1}{n_{h}-1} \sum_{i=1}^{n h}\left(y_{h i}-\bar{y}_{h}\right)^{2}}$ or $\quad s_{h} \sqrt{\frac{1}{n(n-1)} n \sum y^{2}-\left(\sum y\right)^{2}}$ Estimation of the whole population: $y_{s t}=\sum_{h-1}^{L} N_{h} \bar{y}_{h}$

- Estimation of the variance of $\bar{y}_{s t}$ :

$V\left(\bar{y}_{s t}\right)=s^{2}\left(\bar{y}_{s t}\right)=\sum_{h=1}^{L} W_{h}^{2} \frac{s_{h}^{2}}{n_{h}}\left(1-f_{h}\right)$

- Estimation of the variance of the whole population :

$V\left(y_{s t}\right)=N^{2} \cdot V\left(\bar{y}_{s t}\right)$.

- Approximation of the number of degrees of freedom of $s\left(\bar{y}_{s t}\right)$ :

$$
n_{e}=\frac{\left.\sum_{h=1}^{L} g_{h} s_{h}^{2}\right)^{2}}{\sum_{h=1}^{L} g_{h}^{2} s_{h}^{2}} \frac{n_{h}-1}{n_{h}}
$$

with $: g_{h}=N_{h} \frac{\left(N_{h}-n_{h}\right)}{n_{h}}$

Confidence limits :

- estimated mean : $\bar{y}_{s t} \pm t_{p} \times s\left(\bar{y}_{s t}\right)$

with $t_{p}$ obtained from Student's tables for the probability $p$ and the number of degrees of freedom ne.

Optimal allocation :

In order to minimize the variance of $\left(\bar{y}_{s t}\right)$ for a total number of sampled units $n, n_{h}$ must be :

$$
n_{h}=n \frac{N_{h} S_{h}}{\sum_{h=1}^{L} N_{h} s_{h}}
$$


Although tar was one of the commonest pollutants on most of the beaches sampled, we noted the following spectacular dominance of plastic litter, pieces of wood and metallic containers in Brittanny, plastic litter in Indonesia.

\section{II.2 - Analytical methods}

The analytical procedure used in this study has been described elsewhere 4. Briefly after extraction with chloroform in a Soxhlet and complete removal of solvent, some physical parameters (specific gravity, sulfur and metal contents, infrared analysis) could be done on the raw extract. However the analyses carried out by gas chromatography (GC) and UV spectrofluorimetry (SF UV) could be performed once the oil extract had been broken down into paraffinic and aromatic hydrocarbon fractions via conventional adsorption liquid chromatography. The IR spectrum was scanned between $2.000 \mathrm{~cm}$ and $600 \mathrm{~cm}$ on a Perkin Elmer 399B using absorbance mode and a $\mathrm{KBr}$ cell. UV fluorescence was measured on a Perkin Elmer spectrofluorimeter 3.000 equipped with synchronous excitation and emission monochromator modules. The experimental conditions were as follows: excitation slit 10 $\mathrm{nm}$, emission slit $5 \mathrm{~nm}$, scan speed $60 \mathrm{~nm}$ per minute, synchronous scanning of emission and excitation wavelength with $15 \mathrm{~nm}$, a $10 \mathrm{~nm}$ simple quartz sample cell, scanning between 250 and $500 \mathrm{~nm}$. All the samples were analysed with the same conditions $(10 \mathrm{mg} / \mathrm{l})$ and instrument setting to minimize quenching errors. This technique could show the distribution of the aromatic fraction according to the number of aromatic rings in the molecule by a series of peaks at various emission wavelengths. It was an interesting fingerprinting method for comparison between the sample collected in the same area.

Gas chromatographic analyses were carried out on a Hewlett Packard 5840 A model equipped with a flame ionisation detector, splitless injection and a Cp Sil 5 capillary column. The analytical conditions were similar to those described by CALDER et al ${ }^{5}$, for the analysis of crudes oils and petroleum residues by GC. 


\section{III - RESULTS AND DISCUSSION}

\section{III.1. - Tar pollution in Brittanny}

\section{III.1.1 - Assessment of pollution level}

The geographical location of the 81 test sites surveyed along the shoreline of Brittany is represented on fig. 1 by a circle characterizing its level of tar contamination. Each site was sampled on a beach length between 150 and 2.000 $\mathrm{m}(\overline{\mathrm{m}}: 603 \pm 340 \mathrm{~m})$. The total sampled coast is about $50 \mathrm{~km}$. The beaches surveyed were regrouped by "regions" based on coastal geology and exposure (table I). Tar concentrations on the the survey area display high variability according to the geographical location and exposure of the site ${ }^{r_{0}}$ prevailing winds and currents. Usually the standard deviation for a series of test-sites exceeds the mean. The most polluted areas include mainly west facing beaches situated near the Channel western entrance as Sta. 52 at Ushant $(760 \mathrm{~g} / \mathrm{m})$, Sta. $56(242 \mathrm{~g} / \mathrm{m})$ and $57(387 \mathrm{~g} / \mathrm{m})$ at Plouguerneau while the coastline of Bay of Saint-Brieuc and Gulf of Morbihan were not or less polluted. The Breton N.W. coast looked more vulnerable to chronic tar pollution than the S.W. side as a result of the fact that tank washing and deballasting operations could be regarded as the main source of tar pollution along this area. Along the western part (Sta. 18 to Sta. 68) the mean and standard deviation were estimated to the values in gross weight : $76,9 \pm 115,6 \mathrm{~g} / \mathrm{m}$ during our 1982-1983 survey. Tar distribution is strongly depending on the coastal geomorphology and time of sampling. A follow-up study on the accumulation of stranded tar was carried out at Portsall $\left(\mathrm{Sta}_{*}\right.$.53) between September and June 1982. Tar concentration was between $130,4 \mathrm{~g} / \mathrm{m}$ and $251,6 \mathrm{~g} / \mathrm{m}$ with a maximum value in March 3. Tar was one of the commonest pollutants on the beaches sampled and corresponded on some sites: Ushant island (59\%), at Sta. 56 (87\%) Sta. 57 (76 \%) or at Sta. $68(87 \%)$ to the most important pollutant (in weight) found on the beaches. 
In addition to the estimation of tar pollution on beaches discussed above, detailed analytical work was conducted on the oil extract using liquid chromatographic partition (LC), infrared (IR) and synchronous spectrofluorescence (SEES) analyses.

\section{III.1.2 - Chemical characterization of samples collected in Brittany}

The main results on the chemical analysis of 21 samples collected in Brittany are summarized in table II. The oil content in stranded tars generally represents more than $60 \%(62 \pm 23 \%)$ of the tar's dry weight. The percentage of sulfur ranges between 0,99 and $3,98 \%$ wi th an average value of $2,38 \pm$ $0,71 \%$ while the nitrogen content was roughly similar (mean 0,14 $\pm 0,05 \%$ ). The oil extract was fractionned by liquid chromatography into saturated hydrocarbons, aromatic hydrocarbons and heavy products (polar compounds, resins and asphaltens). The relative amount of heavy products in comparison with the hydrocarbon content is represented in table II by the ratio $\mathrm{A}=$ heavy products / saturated and aromatic fractions. The values of this parameter ranged from 0,16 to 0,89 (mean $0,40 \pm 0,25$ ) showed generally a low degree of weathering in comparison with the average value $0,22 \pm 0,06$ measured usually in Middle East and North Africa $\left(+150^{\circ}\right.$ c) oils. This fact was confirmed by IR and GC analyses. The first $\mathrm{n}$ - alkane detected by GC was in most analysed samples below $\mathrm{nC}_{12}$. The volatile fraction defined by the ratio $B=\sum_{10}^{25} n$ - alkanes/ $\sum_{17}^{25} \mathrm{n}$ - alkanes ranged from 1,02 to 2,78 . The mean $(1,67$ $\pm 0,55)$ was lower than the value measured in reference oils ${ }^{4}$ topped at $150^{\circ}$. $(2,01 \pm 0,65)$. According to the $n$ - alkane distribution and the shape of the unresolved envelope, the chromatograms of the analyzed sample have been classified in four patterns: A, B, C and D.Chromatogram A shows a regular distribution of $\mathrm{n}$ - alkanes from $\mathrm{C}_{11}$ to $\mathrm{C}_{40}$ (and more) characteristic of a slightly weathered paraffinic crude oil or light fuel oils. Chromatogram B displays a bimodal $\mathrm{n}$ - alkane distribution with two maxima at approximatively 
$\mathrm{nC}_{17}$ and $\mathrm{nC}_{32}$ characteristic of crude and gas-oil sludges (i.e. tanker wall washings). Chromatogram $\mathrm{C}$ with an unimodal alkane distribution from $\mathrm{C}_{16}$ to more than $\mathrm{C}_{40}$ illustrates the profile of heavy fuel oil similar to refined No 6 fuel or grease with high wax content. Chromatogram D shows only a few detectable GC signals emerging from an unresolved envelope (U.C.M.) characteristic of a highly weathered residue of indetermined origin. Half of the analysed tar sampled on the Breton coast showed a bimodal profile (type B) while a third had an unimodal $\mathrm{n}$ - alkane distribution similar to weathered crude oils (type A) and the remaining portion looked like heavy few oils (type C). These data strongly support transportation activities as the major sources of tar precursors at the western English Channel entrance. This may results from discharges of oily ballast water by small tankers without load on top equipments on inward-bound voyages to north European countries terminals or productive oil fields in the North Sea. Local fishing activities seemed to be a minor contributor since no relationship could be found on the polluted areas between tar loadings and fishing gear (plastic boxes and ropes) lost or discharged at sea ${ }^{6}$. The fact that most samples showed a bimodal $n$ - alkanes distribution was likewise determined along Mediterranean coast 7, 8 but usuallly an unimodal distribution was observed $9,10,11,12$.

So gas chromatography has been useful in showing similarities between samples collecting from different locations, in detecting bimodality or unimodality in tar residues, and in giving some identificative proofs of the possible origin of petroleum products, if the samples are fresh and if comparative reference oil are available. However a lot of tar samples are in different stage of weathering. So in this study GC identifying parameters has been used only on the case of slighly weathered samples ( $<<0,7$ ) showing an unimodal or bimodal n-alkane distribution (types A or B) with a light hydrocarbon content $(\mathrm{B}>1,2)$. In these conditions, the ratios $\mathrm{nC}_{17} /$ Pristane, nC18/Phytane, Pristane/Phytane and biological makers such as the $\mathrm{C}_{20}-\mathrm{C}_{40}$ 
acyclic isoprenoĩds, $\mathrm{C}_{27}+$ steranes and triterpanes could be matched with reference oil samples. Yet pinpointing sources of the stranded beach tars requires in most cases, additional data as sulfur, trace element content, or other Fig. 3 informations obtained by other analytical techniques. In particular Fig. 3 illustrates the relation between Pristane/Phytane ratio and sulfur content values. On account of the weathering processes, a rough correlation was expected with the data from the possible pollutant sources. No analysed tar sample looked like N.A. oils (Algeria and Lybia) or North Sea oil (Ekofisk). On the other hand, a good similitude could be observed with compositional parameters of originating Middle East , or Mexico oils for almost all the tar samples (it is very difficult to differentiate these two kinds of oils in weathered tar samples). One explanation of this possible origin of tar samples could be the relatively low European consumption of other crudes and the difficulty for some North African crudes to form oils patches because of their low asphalten and paraffin contents ${ }^{13}$. Presumptions that some samples (St. 32,40, 64) could be originating from U.S. crude oils are given by GC and sulfur, measurements and the observation of barnacles (lepas anatifera) living on them. It may be that floating tars are colonized soon after they enter the marine environment and that the type of organisms found on them indicates the kind of environment to which they are first exposed. The size of these barnacles ( $\max 15 \mathrm{~mm}$ long) is probably not a reliable measure of the residence time of the tar in the water, until more is known about the factors influencing the growth rates of organisms associated with the tars. However the presence on tar samples of these mollusks unknown on temperate climate should indicated that the discharges occurred far in the open Atlantic ocean before to wash ashore in Brittany under the action of current (Gulf Stream) and W. winds (common in this area). 
III. 2 - Tar pollution on the Indonesian test sites.

III.2.1 - Assessment of pollution level

The general estimation of stranded tar ball pollution on the sites surveyed in 1982 and 1984 is indicated on table III. The data (mean and confidence limits) are expressed in gram per unit beach lenght $(\mathrm{g} / \mathrm{m})$ of the residues collected before (values in gross weight) and after removal of nonpetroleum compound (values in net weight). Oil contents in tar samples was determined by the chemical analyses (Soxhlet extraction) of about fifty samples randomly distributed on each studied test site. The data expressed in net weight represent respectively about $40 \%$ and $30 \%$ of the values in gross weight reported in 1982 and 1984 . So looking only on the data expressed in gross weight may lead to incorrect evaluation and comparison between the pollution level on two sites when the values are very close together. In this study the results expressed in gross or net weight do not change the order in the pollution level of the studied sites. In the other points of the discussion only the values expressed in gross weight will be used.

Kepulauan Seribu in Jakarta Bay appeared to be about one hundred times (1984 survey) and twenty two times (1982 survey) more polluted than the average level measured on Malacca and Makassar test sites. We also observed a great fluctuation of tar pollution during the two seasonal surveys. The tar pollution level determined in May 1984 was three times as high as in August 1982. The increase in deposition in May could be due to a change in the coastal circulation pattern and wind direction during the northwest monsoon. In the case of Malacca straits test sites it was very surprising to find that the area in front of Singapore harbour was among the lowest contaminated zones. This fact could be explained by the presence of strong currents. It seems that the studied sites do not act, as Pulau Pari does, as a trap for tar residues. In this case there is no accumulation of tar but only transit. This was observed in Pulau Takong in the middle of the straits. Fresh tars were coming with the flood tide and going 
back with the ebb tide and the strong drift associated to it. The same portion of the island shore showed a complete redistribution of tar depositions in $24 \mathrm{~h}$ although the level of pollution in weight had not changed.

We observe between August 1982 and May 1984 an increase of tar concentration in Kepulauan Seribu by a factor of about three times. On the other sites no characteristic fluctuations in tar loading are noted when compared to the two surveys. The increase of deposition in May could be due to changes in coastal circulations pattern and wind direction during the northwestern monsoon. At that seasonal period, the weather conditions could be favourable to tar and other wastes floating at sea (sometimes for a long time) to wash ashore in a great deal. In particular on the northern coast the oil depositions were found in soft and smelted conditions due to the heat and thus get mixed with sand to form large lumps discontinuously distributed along the beach. This type of tar distribution was typical of an oil spillage resulting from different sources: tanker accident or tank deballasting at sea, spillage in relation to offshore production activities. The main shipping lanes to and from Jakarta harbour goes northwards the vicinity of Pulau Pari.

\section{III.2.2 - Chemical characterization of samples collected in Indonesia}

More than fifty tar residues were randomly sampled during our 1982 field survey and analysed as previously described. The results are represented in table IV by the average values (mean \pm standard deviation) of oil extract's composition in samples collected in the same area. A strict comparison between the data is difficult because the samples are in different stage of weathering. On the same sampling site we observe that the ratio heavy products/hydrocarbon fractions (A values) has a coefficient of variation (CV\%) between 5 and $62 \%$ (mean $32 \pm 18 \%$ ). However each site showed a particular aspect of tar pollution. For example, on the south coast of Pulau Pari (Kepulauan Seribu area) oil pollution was in form of small tar balls and oil patches 
often lying on the sea bottom at low tidal zone level. The oil content represented about $25 \%$ of the sample's weight. The oil extract had low values of sulfur content $(0,6 \pm 0,7 \%)$ and $\mathrm{nC} 17 /$ Pristane $(0,4 \pm 0,5)$ in comparison with the high Pristane/Phytane value $(7,5 \pm 2,2)$. The northern coast of Pulau Pari was polluted by discontinuous large oily patches lying at the upper beach zone. The contamination seemed to result from the same oil slick. The oil content was very low $(6,6 \pm 0,9 \%)$. The organic extract was characterized by relatively high values for sulfur content $(2,4 \pm 0,9 \%)$ and $\mathrm{n} \mathrm{C} 17 / \mathrm{Pr}(1,6 \pm 0,9)$ and a low $\mathrm{Pr} / \mathrm{Ph}$ value $(1,5 \pm 0,8)$. So these data pointed out that the sources and the origin of oil contamination on the northern coast seemed different from those found of the southern part. The majority of the tar samples collected there (54.\%) displayed a gas chromatogram with a bimodal paraffinic distribution while about $10 \%$ looked like a slighly weathered crude, and $16 \%$ were similar to a heavy fuel oil. All the samples from Pulau Pari North had an unimodal chromatographic profile characteristic of a weathered crude oil. Oil production in Indonesian offshore fields is coming mainly from continental shelves located in the North East and North West Java, Kutei and Natuna basins ${ }^{14}$. The majority of the oil found in these reservoirs is paraffin based from medium to high gravity with a low sulphur content. The main characteristic parameters of analysed Indonesian crude oils may be separated in two groups (table V). Oil sample coming from offshore fields located in the north western part of Kepulauan Seribu labelled I was characterized by a high value of $\mathrm{C}_{17} / \mathrm{Pr}$ and $\mathrm{C}_{18} / \mathrm{Ph}$ ratios while the others $\left(\mathrm{I}_{2}\right.$ to $\left.\mathrm{I}_{5}\right)$ had a high $\mathrm{Pr} / \mathrm{Ph}(9,2 \pm 0,3)$ and a low value $\mathrm{nC}{ }_{17} / \operatorname{Pr}(0,33 \pm 0,12)$ values. Most Indonesian oils have a low sulfur content ( $<<0,4 \%$ ). 
The values of $\mathrm{Pr} / \mathrm{Ph}$ ratio with sulfur contents measured in

Fig 4. Kepulauan Seribu tar samples are represented on the Fig. 4. We observed on this graph that the data of samples labelled 1, 2, 4, 5, 7 were grouped with oils $\mathrm{I}_{2}$ to $I_{5}$ while samples $14,16,17,18,19$ seemed to be similar to reference oils from Middle East, Africa or Mexico. In order to get better identifying proofs about the possible origin of tar samples, analyses by infrared spectrometry and synchronous spectrofluorimetry were carried out. Various non linear combination of IR absorbance ratios are possible ${ }^{15}$. A determination limited to the absorbance at the frequences $1600 \mathrm{~cm}^{-1}, 810 \mathrm{~cm}^{-1}$ and $720 \mathrm{~cm}^{-1}$ provides an additional tool for oil identification. In particular an interesting recognition of

Fig. 5. tar samples probably coming from Indonesian crude oil $\mathrm{I}_{1}$ could be noticed on Fig. 5 .

The aromatic extracts from tar balls were analysed using synchronous fluorescence spectroscopy technique. The method is based on the fact that the fluorescence maxima of aromatic compounds occur at different emission wavelengths according to the aromatic structure. Thus oils of similar origin have unique mixture of aromatic compounds which exhibit characteristic luminescence fingerprint. The intensities of the fluorescence spectra were measured at wavelengths corresponding to peak maxima at $280-300 \mathrm{~nm}$ (1 ring), 310-320 $\mathrm{nm}$ (2 rings), 365-410 nm (3 - 4 rings)390-480 nm (5 and larger rings). Synchronous scannig of fluorescence from 250 to $500 \mathrm{~nm}$ revealed significant qualitative differences in the spectra of samples from different locations. The relative contribution to fluorescence by five rings and larger aromatic compounds was determined by expressing the peak height at $405 \mathrm{~nm}$ in relation to the value at $350 \mathrm{~nm}$ (I 405/I 350). A rough correlation could be expected between the values in tar balls and in its possible crude oil sources on account of the relative solubility of light aromatic hydrocarbons in sea water before lump and tar ball formation from the spilled oil. However these analytical data seemed roughly in agreement with the other identifying parameters to assess the 
possible source and origin of the pollution in each studied site.

I - South Pulau beaches showed a widespread tar contamination probably resulting from several sources. Most of samples displayed a gas chromatogram with a bimodal paraffinic distribution characteristic of tanker sludge residues or gas-oils and analytical parameters similar to Indonesian oils labelled $\mathrm{I}_{2}$ to $\mathrm{I}_{5}$. In this area, pollution could be mainly attributed to local shipping and fishing activities. About ten percent of samples looked like weathered crude oils (type $I_{1}$ ) probably coming from offshore activities in N.W. Kepulauan Seribu area while about twenty percent of tar samples were assigned to foreign countries oils.

2 - Oil pollution on the north Pulau Pari coast was mainly made of large oily patches homogeneoustly distributed along the upper flat. All the samples are characterized by an unimodal gas chromatogram pattern and a sulfur content value similar to that of many oils produced in the Middle East countries. This coast is particularly exposed to chronic pollution with its localisation in the vicinity of the main shipping routes to and from Jakarta harbour.

3 - Pulau Tikus showed the lowest level of oil contamination in the studied area. The main analytical parameter of the collected samples could be compared to those found on South Pulau Pari coast.

4 - The level of tar accumulation at the Kepulauan Riau area was relatively low $(16 \mathrm{~g} / \mathrm{m})$ in spite of the important traffic accross the Straits of Malacca. Twenty two samples were collected on the surveyed areas. Three samples were characterized by a sulfur content higher than 1, all the others had a low value $(\overline{\mathrm{m}}: 0,33 \pm 0,18 \%)$. Two third of the analysed samples had a GC pattern looking like lightly weathered crude oils and only three samples showed a bimodal distribution characteristic of tanker sludge residues. 
Sulfur content, GC and IR data of the collected samples were arranged in two main groups. About one third of them were grouped around the reference oil $I_{1}$ while the others could be correlated with oils from other Indonesian or South Asia oil fields similar to reference oils labelled $\mathrm{I}_{2}$ to $\mathrm{I}_{5}$. 5 - The two other pilot areas: Langga beach on the western coast of Sulawesi (Makassar Straits) and Kukup beach on the Central Java coast were characterized by a low tar pollution. All the analysed tars had a low sulfur content ( $\tilde{m}$ : $0,3 \pm 0,3)$. One sample showed a bimodal $n$ - alkane distribution while the others seemed to be weathered crude oils of indetermined origin. 


\section{CONCLUSION}

This paper gives a first assessment and characterization of tar depositions on some sites in French Brittany and Indonesia vulnerable to chronical oil pollution. The main results are compared in table VI with data obtained on some areas more extensively studied as Mediterranean, Gulf of Mexico or Kuwait coastlines. Stranded tar pollution on Kepulauan Seribu (Jakarta Bay) during our 1982 and 1984 surveys was among the highest values found on coastal areas of major tanker routes as Kuwait, Bermuda or Israel. Pollution levels observed along Malacca and Makassar Straits are comparable with the less polluted coastlines such as Trinidad and Tobago coasts. With an estimation of about $80 \mathrm{~g} / \mathrm{m}$, the western part of Brittany is notabily subjected to oil contamination.

The characterization of tar samples is important in order to define the possible pollutant sources and origin. The classification of samples was based on sulfur content, gravimetric and molecular compositions (gas chromatography), IR and fluorescence spectra. Tar samples collected in Brittany looked very fresh; so sulfur content and gas chromatographic data were a good approach for identifying oil pollutants. On the other hand, most tars collected in Indonesia significant marks of degradation and it was necessary to use other fingerprinting methods as biological markers ${ }^{22}$ (triterpanes and steranes) or infrared and fluorescence spectra.

\section{ACKNOWLEDGEMENTS}

We would like especially to thank Mr M. JOANNY, J.L. LHEVEDER, B. PRASEYTO for their skilful field assistance and their help in the data processing and Mrs E.H. LEGOWO for some chemical analyses on the Indonesian samples. 


\section{REFERENCES}

1 - National Academy of Sciences (NAS) 1975. Petroleum in the Marine Environment. NAS Washington

2 - UNESCO. Manuel de surveillance continue du pétrole et des hydrocarbures en mer et sur les plages. COI/OMS/PNUE. 1977 Supp. 2 Paris

UNESCO. Manual and guides, $1982 \mathrm{n}^{\circ} 11,38 \mathrm{pp}$.

3 - L. LOUBERSAC. Pollution chronique des plages par les résidus pétroliers. CNEXO-MRE report 1982, 26 pp.

4 - G. BODENNEC. Pollution du littoral français par les macrodéchets. Analyse des résidus pétroliers. CNEXO-MRE report 1983, 106 pp.

5 - J.A. CALDER and P.D. BOEHM in the International Symposium on the Amoco Cadiz: Fates and effects of the oil spill. Brest (France) Nov. 19-22 1979. CNEXO Paris 1981, pp. 149-158

6 - J.L. LHEVEDER. Pollution du littoral armoricain par les macrodéchets. CNEXO-ENITRTS report 1983, 167 pp.

7 - J. AlBAigES, J. BORDON and J. ROS. IVèmes journées Etud. Pollutions. C.I.E.S. Antalya, 103 (1978)

8 - V. SHEKEL and R. DAVID. Envir. Sci. Technol. 11, 502 (1977)

9 - J.N. BUTLER. Mar. Chem. $\underline{3}, 9$ (1975)

10 - L.M. JEFFrey, W.E. PEQUenAt, E.A. KENNEDY, A. VOS, B.M. JAMES. Marine Pollution Monitoring (Petroleum) NBS SP 409, 1974 Washington D.C. pp. $234-235$

11 - G. BodenneC, L. Loubersac, J. Bilal, E.H. Legowo and B. PRASEYTO Occurrence of tar pollution along shores in Indonesia in August 1982. CNEXO-LEMIGAS report 1983,110 pp.

12 - M.C. KENNICUTT and J.M. BROOKS. Marine Pollution Bulletin 14, 335 (1983) 
13 - M. SAVAGE and C.H. WARD. Marine Pollution Bulletin 15, 174 (1984)

14 - J. BILAL and W.W. KUHNHOLD. Marine oil pollution in Southeast Asia. FAO/UNEP, SCS/80/WP/92 Manila 1980; 85 pp.

15 - J.S. MATTSON. Classification of oils by the application of pattern recognition techniques to infrared spectra. US Department of transportation Washington D.C. 1976, 45 pp.

16 - S.G. WAKEHAM. Environ. Sci. Technol. 11, 272 (1977)

17 - B.L. OOSTDAm. Mar. Pollut. Bull., 11, 301 (1984)

18 - C. GEORGES and B.L. OOSTDAM. Mar. Pollut. Bull., 14, 170 (1983

19 - B.L. OOSTDAM and W. ANDERLINI. Oil spills and tar pollution along the coast of Kuwait. Mar. Pollut. Program KISR, Special report (1978)

20 - J.N. BUTLER, B.F. MORRIS and J.SASS. Pelagic tar from Bermuda and the Sargasso Sea. Bermuda Biological Station Spec. Publ. No 10 (1973)

21 - S.D. WAHBY and K.Z. EL DEEB. A study of the state of pollution by petroleum hydrocarbons along the Alexandria coast. V Journées Etud. Pollut. CIESM (1980)

22 - J. AlBAIgES, and J. BORBON. J of chromatography 204, 491 (1981) 
(October 1982 - January 1983 survey)

Survey area

(test site $n^{\circ}$ ) total length tar concentration $(\mathrm{g} / \mathrm{m})$

tar/other litter

sampled $(\mathrm{km})$ range

\section{Loire Atlantique}

Sta 1 - Sta 10

5,6

$0-49$

$12,2 \pm 15,9$

$1,7 \pm 2,2$

max Sta 5: 5,8\%

\section{Morbihan}

Sta 11 - Sta 20

4,4

$0-82$

$7,9 \pm 27,3$

$2,3 \pm 1,4$ $\max$ Sta 18: 3,8\%

Sta $21-$ Sta 26

3,5

$10-208$

$57 \pm 72$

$4,9 \pm 4,3$

$\max$ Sta 26: $12,5 \%$

Finistère

Sta 27 - Sta 32

3,3

$0-88$

$42,1 \pm 46,7$

$4,8 \pm 1,6$

max Sta 32: 6,5\%

Sta 33 - Sta 38

$$
5,3
$$

$0-203$

$72,2 \pm 75,2 \quad 11,4 \pm 13,4$ max Sta 37: $33,9 \%$

Sta 39 - Sta 44

5,2

$15-235$

$91 \pm 84$

$10,0 \pm 56$ max Sta 39: $16,8 \%$

Sta 45 - Sta 50

3,6

$0-142$

$35,2 \pm 54,2$

$11,2 \pm 15,2$

$\max$ Sta 49: $37,5 \%$

Sta 51 - Sta 56

3,4

$12-760$

$197 \pm 296$

$35,0 \pm 30,2$

max Sta 56: $87,4 \%$

Sta 57 - Sta 61

3,6

$0-387$

$65 \pm 160$

$36,9 \pm 30,6$

max Sta 57: $75,6 \%$

\section{Côtes-du-Nord}

Ille-et Vilaine

Sta 62 - Sta 71

4,3

$0-130$

$36 \pm 49$

$32,1 \pm 40,4$

max Sta 65: 94,8\% 


\begin{tabular}{|c|c|c|c|c|c|c|c|c|c|}
\hline \multirow[t]{2}{*}{ Sampling site } & \multirow{2}{*}{$\begin{array}{l}\text { station } \\
\text { site } n^{\circ}\end{array}$} & \multirow{2}{*}{$\begin{array}{r}\text { oil } \\
\text { content } \\
(\mathbf{x})\end{array}$} & \multirow{2}{*}{$\begin{array}{r}\text { sulfur } \\
\text { content } \\
(\mathbf{m})\end{array}$} & \multirow{2}{*}{$\begin{array}{l}\text { A } \\
\text { (1) }\end{array}$} & \multicolumn{3}{|c|}{ gas chromatography } & \multirow[b]{2}{*}{$\frac{\mathrm{nC}_{18}}{\mathrm{Ph}}$} & \multirow[b]{2}{*}{$\frac{\mathrm{Pr}}{\mathrm{Ph}}$} \\
\hline & & & & & $\begin{array}{r}\text { profile } \\
\text { type }\end{array}$ & $\begin{array}{l}B \\
(2)\end{array}$ & $\frac{\mathrm{nC}_{17}}{\mathrm{Pr}_{\mathrm{r}}}$ & & \\
\hline Pornichet & 7 & 40,2 & 2,08 & 0,16 & A & 0,99 & 0,92 & 0,77 & 1,78 \\
\hline Erdeven & 21 & 42,5 & 2,02 & 0,70 & B & 2,70 & 1,76 & 0,73 & 1,21 \\
\hline Graves & 22 & 92,5 & 2,09 & 0,47 & B & 2,28 & 1,60 & 0,79 & 1,78 \\
\hline Kerfriant & 29 & 70,5 & 2,36 & 0,43 & B & 2,06 & 1,50 & 0,83 & 2,78 \\
\hline Sables Blancs & 32 & 56,9 & 2,06 & 0,19 & B & 1,61 & 3,02 & 2,02 & 2,73 \\
\hline Kervellec & 33 & 39,7 & 2,45 & 0,86 & A & 1,91 & 1,50 & 0,71 & 1,21 \\
\hline La Torche & 34 & 18,9 & 2,38 & 0,78 & C & 0,14 & 0,20 & 1,10 & 1,29 \\
\hline Pors Peron & 39 & 86,4 & 2,05 & 0,36 & A & 2,38 & 2,20 & 1,03 & 1,58 \\
\hline Plage du Ris & 40 & 74,4 & 0,99 & 0,18 & $\mathrm{C}$ & 0,44 & 0,83 & 1,98 & 1,22 \\
\hline Trez-Bellec & 42 & 53,4 & 3,21 & 0,25 & $\mathrm{C}$ & 0,59 & 0,50 & 0,63 & 1,25 \\
\hline Aber & 43 & 82,9 & 1,49 & 0,89 & B & 2,45 & 1,82 & 0,72 & 1,69 \\
\hline La Palud & 44 & 89,8 & 2,27 & 0,43 & B & 1,53 & 1,29 & 0,74 & 1,21 \\
\hline Toulinguet & 46 & 71,3 & 1,78 & 0,55 & B & 1,90 & 1,60 & 0,76 & 1,80 \\
\hline Plougastel & 48 & 86,2 & 3,20 & 0,25 & B & 2,13 & 0,91 & 0,42 & 1,46 \\
\hline Posmilin & 49 & 80,7 & 2,80 & 0,60 & B & 1,44 & 1,17 & 0,71 & 1,10 \\
\hline Blancs Sablons & 50 & 72,8 & 3,98 & 0,78 & $\mathrm{C}$ & 0,19 & 0,20 & 1,30 & 1,02 \\
\hline Portsall & 53 & 89 & 3,28 & 0,58 & A & 3,2 & 2,60 & 0,89 & 2,11 \\
\hline Bouenou & 54 & 50,7 & 2,22 & 0,85 & B & 2,02 & 1,23 & 0,70 & 1,49 \\
\hline Vougeot & 56 & 50,7 & 2,82 & 0,36 & A & 2,30 & 2,68 & 0,86 & 2,37 \\
\hline Roscoff & 59 & 24,6 & 3,07 & 0,30 & B & 1,08 & 0,90 & 0,77 & 1,80 \\
\hline Trozoul & 64 & 28,5 & 1,48 & 0,25 & A & 2,51 & 2,35 & 1,09 & 2,45 \\
\hline
\end{tabular}

[1] $A=$ Heavy products (\%)/saturated + aromatic hydrocarbons (\%)

[2] $B=\sum_{10}^{25} n$ - alkanes $/ \sum_{17}^{25} n$ - alkanes 
Table III

TAR POLLUTION ON INDONESIAN BEACHES

in August 1982 and May 1984

(data expressed in $\mathrm{g} / \mathrm{m}$ )

\begin{tabular}{|c|c|c|c|c|}
\hline \multirow[b]{2}{*}{ Geographical location } & \multicolumn{2}{|c|}{1982 survey } & \multicolumn{2}{|c|}{1984 survey } \\
\hline & $\begin{array}{l}\text { mean in } \\
\text { gross weight }\end{array}$ & $\begin{array}{l}\text { mean in } \\
\text { net weight }\end{array}$ & $\begin{array}{l}\text { mean in } \\
\text { gross weight }\end{array}$ & $\begin{array}{l}\text { mean in } \\
\text { net weight }\end{array}$ \\
\hline Pulau Pari South & $102 \pm 45$ & $25,9 \pm 11,4$ & $542 \pm 394$ & $112,3 \pm 85,8$ \\
\hline Pulau Pari North & $2867 \pm 840$ & $189 \pm 55$ & $9554 \pm 5979$ & $1880 \pm 1224$ \\
\hline Pulau Tikus & $61,1 \pm 49,4$ & $18,1 \pm 10,8$ & $86 \pm 37,8$ & $19,8 \pm 9,8$ \\
\hline $\begin{array}{l}\text { General estimation at } \\
\text { Kepulauan Seribu }\end{array}$ & $812,7 \pm 219$ & $67 \pm 15,3$ & $2460 \pm 1349$ & $494 \pm 270$ \\
\hline Pulau Takong & $29,8 \pm 18,2$ & $8,14 \pm 7$ & $53,6 \pm 77,6$ & $13,7 \pm 19,8$ \\
\hline Pulau Pelampong & $15,2 \pm 16,5$ & $7,6 \pm 8,2$ & 6,57 & 0,95 \\
\hline Pulau Nirup & $11,3 \pm 13,1$ & $8,5 \pm 9,9$ & $5,21 \pm 9,64$ & $1,68 \pm 3,10$ \\
\hline Pulau Labon Kecil & $9 ; 6 \pm 13,7$ & $5,5 \pm 7,9$ & $2,85 \pm 1,88$ & $1,02 \pm 0,67$ \\
\hline Pulau Kapal Besar & $24,1 \pm 20,7$ & $11,3 \pm 10,1$ & $41,2 \pm 37,8$ & $18,3 \pm 16,8$ \\
\hline $\begin{array}{l}\text { General estimation at } \\
\text { Kepulauan Riau }\end{array}$ & $15,4 \pm 5,4$ & $7,8 \pm 3,4$ & $16,03 \pm 12,4$ & $4,80 \pm 2,95$ \\
\hline Makassar Straits (Langga) & $56,8 \pm 36,5$ & $30,7 \pm 21,1$ & $22,6 \pm 9,3$ & $9,08 \pm 3,32$ \\
\hline Central Java coast (Kukup) & $<1$ & & $7,5 \pm 2,7$ & $3,13 \pm 2,53$ \\
\hline
\end{tabular}




\begin{tabular}{|c|c|c|c|c|c|c|c|}
\hline test site & $\begin{array}{l}\mathrm{nb} \text {. of } \\
\text { samples }\end{array}$ & $\begin{array}{l}\text { oil content } \\
\text { mean } \pm \text { s.d. }\end{array}$ & $\begin{array}{l}\text { sulfur }(\%) \\
\text { mean } \pm \text { s.d. }\end{array}$ & $\begin{array}{l}A \\
(1)\end{array}$ & $\begin{array}{r}\text { G.C. p } \\
\text { mean } \pm \\
\mathrm{nC}_{17} / \mathrm{Pr}\end{array}$ & $\begin{array}{l}\text { arameters } \\
\text { s.d. } \\
\mathrm{Pr} / \mathrm{ph}\end{array}$ & $\begin{array}{l}\text { UV SF (2) } \\
\text { I } 405 / I \quad 350\end{array}$ \\
\hline \multicolumn{8}{|l|}{ Kepulauan Seribu area } \\
\hline Pulau Pari South & 13 & $25,4 \pm 10,4$ & $0,6 \pm 0,7$ & $0,7 \pm 0,4$ & $0,4 \pm 0,5$ & $7,5 \pm 2,2$ & $0,7 \pm 0,1$ \\
\hline Pulau Pari North & 6 & $6,6 \pm 0,9$ & $2,4 \pm 0,9$ & $0,5 \pm 0,2$ & $1,6 \pm 0,9$ & $1,5 \pm 0,8$ & $0,5 \pm 0,1$ \\
\hline Pulau Tikus & 5 & $48,7 \pm 40,9$ & $0,3 \pm 0,1$ & $0,8 \pm 0,5$ & $1,2 \pm 1,0$ & $3,5 \pm 0,8$ & $0,4 \pm 0,2$ \\
\hline \multicolumn{8}{|l|}{ Kepulauan Riau area } \\
\hline Pulau Takong & 5 & $24,1 \pm 11,4$ & $0,6 \pm 0,4$ & $0,2 \pm 0,02$ & $0,7 \pm 0,1$ & $6,7 \pm 1,0$ & $0,9 \pm 0,2$ \\
\hline Pulau Pelampong & 2 & $50 \pm 30$ & $1,1 \pm 1,1$ & $0,4 \pm 0,1$ & $1,1 \pm 0,4$ & $5,8 \pm 0,5$ & \\
\hline Pulau Nirup & 8 & $69,5 \pm 16,2$ & $0,4 \pm 0,3$ & $0,3 \pm 0,1$ & $0,7 \pm 0,1$ & $6,6 \pm 0,6$ & $0,7 \pm 0,1$ \\
\hline Pulau Labou Kecil & 3 & $67,1 \pm 17,2$ & $0,3 \pm 0,2$ & $0,4 \pm 0,02$ & $1,8 \pm 0,2$ & $3,7 \pm 0,5$ & $0,6 \pm 0,1$ \\
\hline Pulau Kapal Besar & 3 & $46,9 \pm 6,2$ & $0,5 \pm 0,2$ & $1,0 \pm 0,3$ & & & \\
\hline Makassar Straits (Langga) & 4 & $53,4 \pm 17,9$ & $0,3 \pm 0,3$ & $0,6 \pm 0,2$ & $1,1 \pm 0,5$ & $3,2 \pm 0,4$ & $0,4 \pm 0,1$ \\
\hline Central Java coast & 2 & $81,2 \pm 11,7$ & $0,3 \pm 0,1$ & $0,9 \pm 0,2$ & 1,3 & 2,6 & $0,7 \pm 0,1$ \\
\hline
\end{tabular}

(1) as defined in table II

(2) as defined in this paper 
Table V: Physico-chemical and chromatographic characteristics of some reference oils

\begin{tabular}{|c|c|c|c|c|c|c|c|}
\hline \multirow[t]{2}{*}{ sample } & \multirow{2}{*}{$\begin{array}{c}\text { code } \\
n b\end{array}$} & \multirow{2}{*}{$\begin{array}{l}\text { sulphur } \\
\text { content }\end{array}$} & \multirow{2}{*}{$\begin{array}{r}A \\
(1)\end{array}$} & \multicolumn{3}{|c|}{ G.C. parameters } & \multirow{2}{*}{$\begin{array}{rr} & \text { UV } \\
\text { I } 405\end{array}$} \\
\hline & & & & $\mathrm{C}_{17} / \mathrm{Pr}$ & $\mathrm{C}_{18} / \mathrm{Ph}$ & $\mathrm{Pr} / \mathrm{Ph}$ & \\
\hline \multicolumn{8}{|c|}{ Indonesian crudes } \\
\hline I IAP & I1 & 0,10 & 0,28 & 3,55 & 8,20 & 3,30 & 0,92 \\
\hline AR PT \# 2 & I2 & 0,13 & 0,26 & 0,40 & 4,47 & 9,20 & 0,39 \\
\hline AR DST \# 3 & I3 & 0,16 & 0,25 & 0,48 & 4,66 & 8,78 & 0,32 \\
\hline AR DST \# 4 & I4 & 0,30 & 0,18 & 0,25 & 3,09 & 9,40 & 0,36 \\
\hline AR DST \# 5 & I5 & 0,12 & 0,18 & 0,20 & 2,51 & 9,45 & 0,41 \\
\hline
\end{tabular}

Middle East oils

$\begin{array}{llllllll}\text { Arabian light }(+150) & \text { Ar } & 1,82 & 0,44 & 5,66 & 2,44 & 0,46 & 0,55 \\ \text { Iranian light (+ 150) } & \text { Ir } & 1,85 & 0,29 & 5,92 & 2,81 & 0,55 & 0,55 \\ \text { Iraq (crude) } & \text { Iq } 1,81 & 0,27 & 6,96 & 2,98 & 0,50 & 0,50\end{array}$

Other countries

$\begin{array}{llllllll}\text { Nigeria } & \text { Ng } & 0,30 & 0,07 & 0,61 & 2,19 & 0,55 & 0,34 \\ \text { Gabon (Mandji) } & \text { Ga } & 1,10 & 0,11 & 1,06 & 0,69 & 0,35 & 0,32 \\ \text { Mexico (Ixtoc) } & \text { Mx } & 1,80 & 0,16 & 3,64 & 2,28 & 0,61 & 0,40 \\ \text { North sea (Ekofish) } & \text { Ek } & 0,22 & 0,16 & 2,53 & 2,72 & 1,23 & 0,18 \\ \text { Algeria(Hassi Messaoud) } & \text { Ah } & 0,13 & 0,19 & 2,75 & 3,40 & 1,40 & - \\ \text { Algeria (Zarzetine) } & \text { Az } & 0,08 & 0,21 & 3,03 & 3,49 & 1,44 & - \\ \text { Libya (Zueitina) } & \text { Lz } & 0,23 & 0,13 & 2,58 & 1,60 & 1,68 & - \\ \text { Venezuela (Boscan) } & \text { Vb } & 5,5 & 1,08 & 0,62 & 0,51 & 0,83 & 0,33 \\ \text { U. S. A. (Texas) } & \text { Ut } & 1,0 & 0,07 & 1,25 & 4,40 & 4,80 & - \\ \text { U. S. A. (Luisiana) } & \text { U1 } & 1,1 & 0,07 & 1,10 & 3,0 & 2,73 & -\end{array}$

(1) defined as table IV.

(2) spectrofluorescence data defined by the ratio of fluorescence intensity at $405 \mathrm{~nm}$ and at $350 \mathrm{~nm}$. 


\begin{tabular}{|c|c|c|c|}
\hline location & $\begin{array}{l}\text { beach } \\
\text { profiles } \\
\text { Nos. }\end{array}$ & $\begin{array}{l}\text { tar concentration } \\
(\mathrm{g} / \mathrm{m}) \\
\text { mean } \pm \mathrm{s} . \mathrm{d} .\end{array}$ & references \\
\hline The Netherlands (North Sea) & 10 & $0,2 \pm 0,3$ & 17 \\
\hline Australia (Darwinand vicinity & 8 & $0,4 \pm 1$ & 17 \\
\hline Mauritus (regional average) & 46 & $5,5 \pm 9,7$ & 17 \\
\hline Indonesia (Sumatra Sibolga) & 12 & $1,4 \pm 4,7$ & 17 \\
\hline Indonesia Central Java coast & 5 & $7,5 \pm 2,7$ & this study \\
\hline Seychelles (Mahi) & 32 & $10,1 \pm 12,3$ & 17 \\
\hline Singapore (regional average) & 19 & $10,0 \pm 1,2$ & 17 \\
\hline India (West coast) & 35 & $13,1 \pm 15,6$ & 17 \\
\hline Indonesia (Malacca straits) & 32 & $16,0 \pm 12,4$ & this study \\
\hline Thailand (gulf average) & 38 & $17,8 \pm 36,6$ & 17 \\
\hline South Africa (Cape Town & & & \\
\hline Durban vicinity) & 43 & $27,8 \pm 15,6$ & 17 \\
\hline Indonesia (Makassar straits) & 12 & $22,5 \pm 9,3$ & this study \\
\hline Saudi Arabia (Jedda) & 3 & $29,8 \pm 27,4$ & 17 \\
\hline Kenya (regional average) & 14 & $42,8 \pm 40,8$ & 17 \\
\hline Sri Lanka (regional average) & 38 & $46,4 \pm 51,4$ & 17 \\
\hline Trinidad and Tobago & & 54 & 18 \\
\hline Sudan (Port Sudan vicinity) & 10 & $107,1 \pm 87,8$ & 17 \\
\hline France (W. Brittany) & 50 & $76,9 \pm 115,6$ & this study \\
\hline Malaysia (Gulf of Thailand) & 43 & $125,1 \pm 129,4$ & 17 \\
\hline Kuwait (regional average) & 58 & $155,1 \pm 87,1$ & 19 \\
\hline Bermuda & & 700 & 20 \\
\hline Indonesia (Kepulaúan Seribu) & 47 & $813 \pm 219$ & 1982 survey \\
\hline Indonesia (Kepulauan Seribu) & 47 & $2460 \pm 349$ & 1984 survej \\
\hline \multicolumn{4}{|l|}{ Israel } \\
\hline (Mediterranean coast) & & 3625 & 21 \\
\hline
\end{tabular}




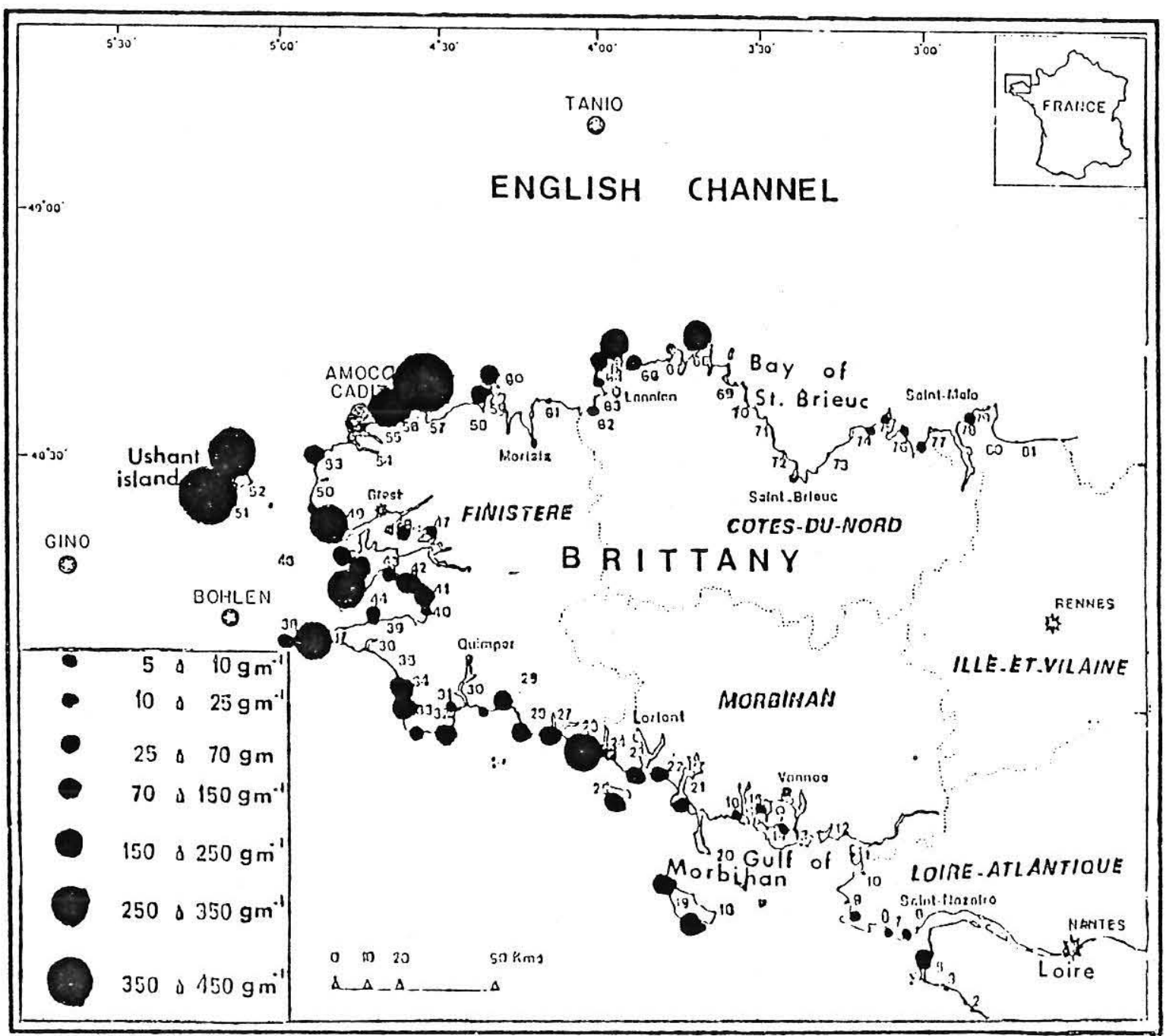

Fig. 1 - Localisation of studied sites and distribution of tar pollution on Brittany (France) 


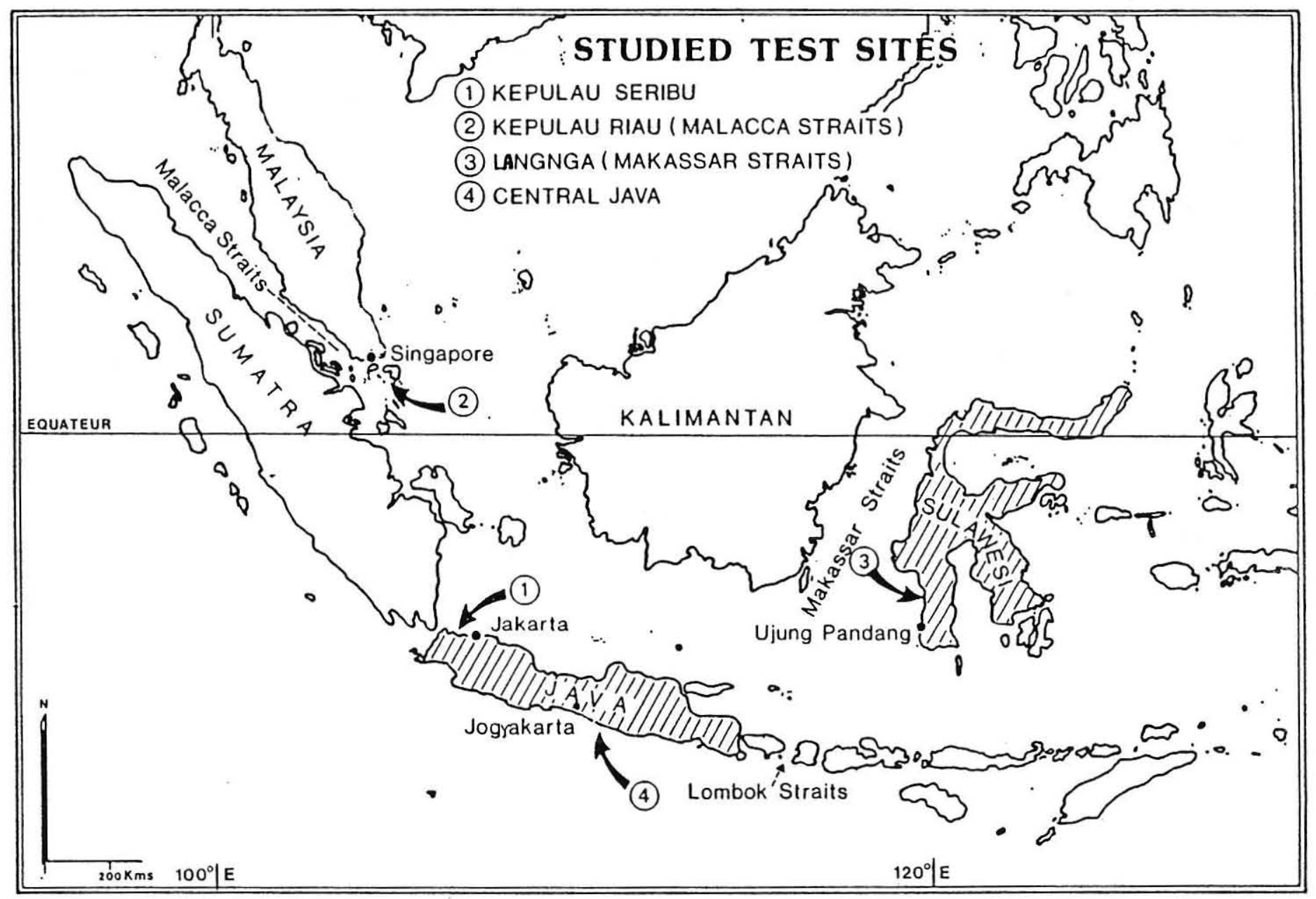

Figure 2 - Studied test sites along shores in Indonesia 


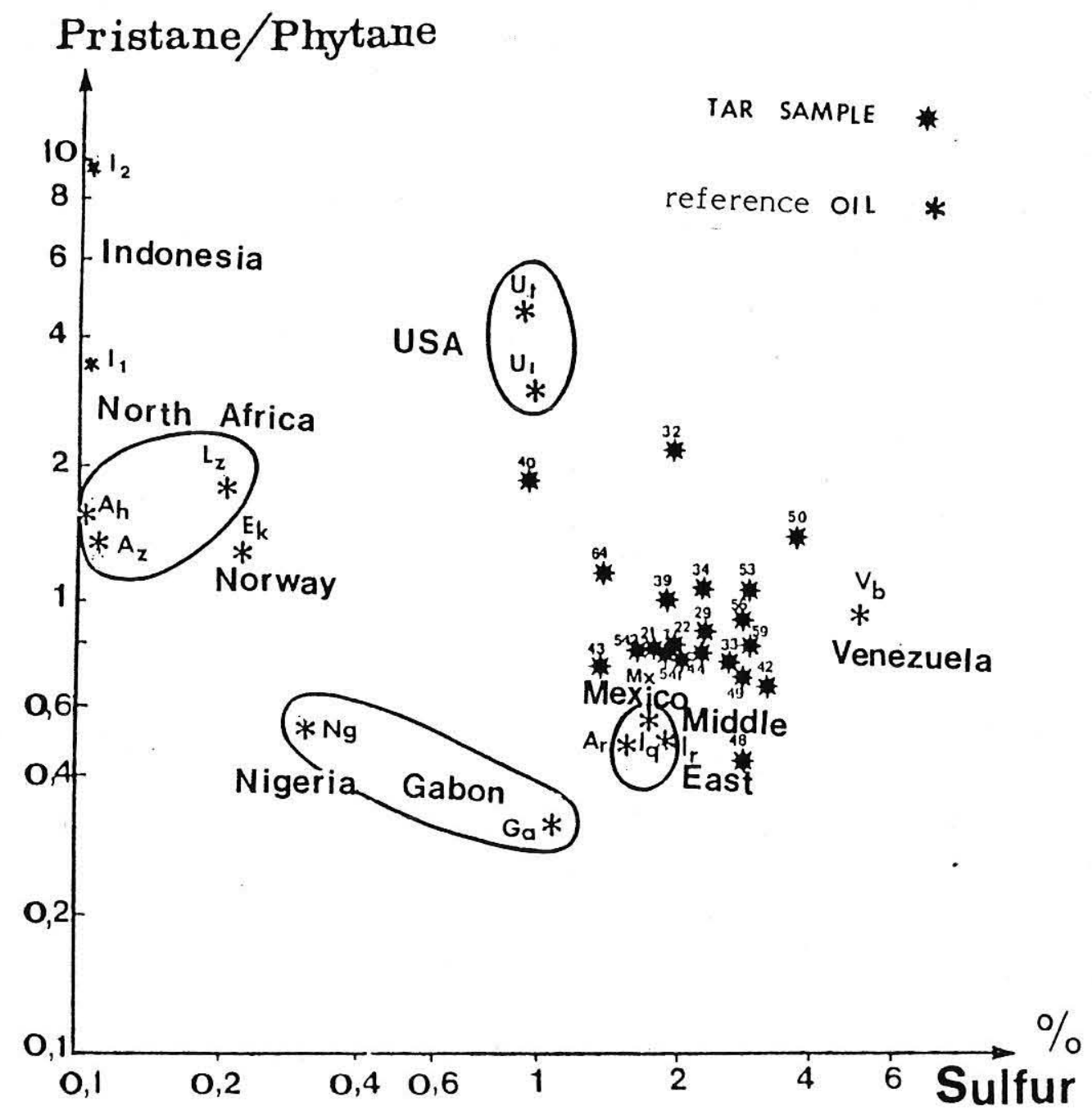

Figure 3 - Relationship between pristane/phytane ratio and sulfur content in tar samples collected in Brittany (France) 


\section{KEPULAU SERIBU}

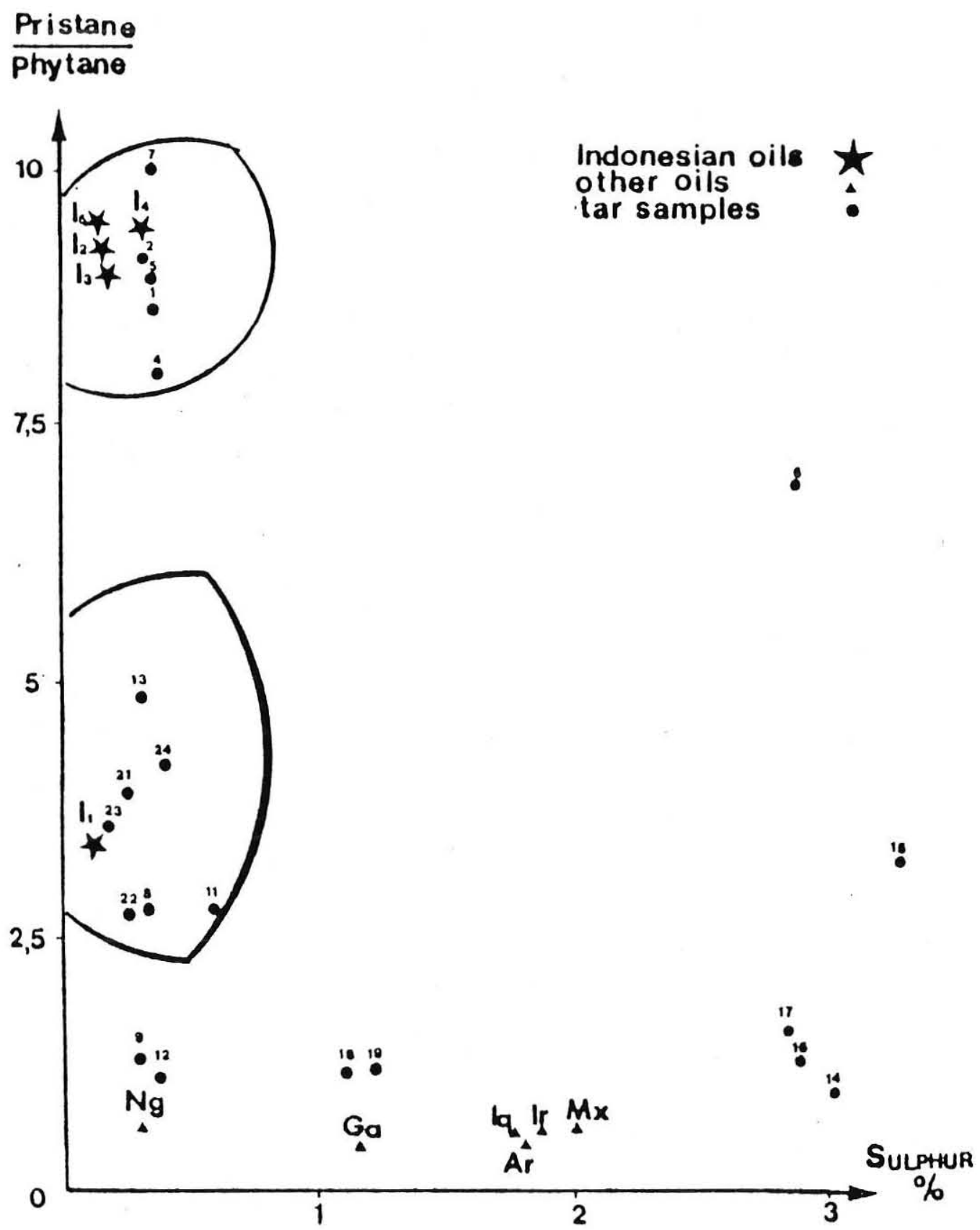

Figure 4 - Relationship between pristane to phytane ratio and sulfur content in Kepulau Seribu samples 